Dialectologia 15 (2015), 137-156.

ISSN: 2013-2247

Received 24 December 2014.

Accepted 16 March 2015.

\title{
NASALITY AND VOICING IN NON-STANDARD DIALECT OF MALAY
}

\author{
Sharifah Raihan SYED JAAFAR \\ National University of Malaysia \\ s_raihan@ukm.edu.my
}

\begin{abstract}
This study discusses nasality and voicing in non-standard dialect of Malay i.e. Perak dialect (PD). As is widely claimed in previous Malay scholars, nasal substitution applies when there is a sequence of nasal and voiceless obstruent by no means to avoid the cluster from emerging in the surface representation. In this analysis, I argue that nasal substitution is not always applied in PD when there is a sequence of nasal and voiceless obstruent. The sequence is permitted to emerge root-internally in the dialect. In this analysis, I will also argue that nasal substitution is not only applied to voiceless obstruents, but it also applies to voiced obstruents after nasal segments. I suggest that the application of nasal substitution in both voiced and voiceless obstruents as occurred in the dialect is to satisfy CRISP-EDGE[s] which rules out candidates with both nasal and voiceless/voiced obstruent clusters in the surface representation.
\end{abstract}

\section{Keywords}

nasality and voicing, voiced obstruents nasal substitution, Malay, Optimality theory

\section{NASALIDAD Y SONORIDAD EN UN DIALECTO NO ESTÁNDAR DEL MALAYO}

\section{Resumen}

Este estudio analiza la nasalidad y sonoridad en un dialecto no estándar del malayo, el dialecto Perak. Como es ampliamente reivindicado por previos estudios sobre el malayo, la sustitución nasal se aplica cuando hay una secuencia de nasal y obstruyente sorda que no evita de ningún modo el clúster emergente en la representación superficial. En este análisis, se argumenta que la sustitución nasal no siempre se aplica en el dialecto Perak cuando hay una secuencia de nasal y obstruyente sorda, la cual se permite que 
aparezca en el radical subyacente del dialecto. En este análisis, también se argumentará que la sustitución nasal no sólo se aplica a las obstruyentes sordas sino también a las sonoras después de segmentos nasales. Se sugiere que la aplicación de la sustitución nasal en obstruyentes sonoras y en sordas como ocurre en el dialecto es para satisfacer CRISP-EDGE[s], cuyas reglas descarta candidatos con clústers de nasal y de obstruyente sorda/sonora en la representación superficial.

\section{Palabras clave}

nasalidad y sonoridad, substitución de obstruentes nasales sonoras, Malayo, Teoría de la Optimidad

\section{Introduction}

As is widely claimed in Malay literatures (e.g.: Hassan, 1974, 1987; Omar, 1975; Karim, 1995; Onn, 1980), voiceless obstruents following nasal segments in standard Malay (henceforth SM) have to undergo nasal substitution. This is because the language does not permit nasal and voiceless obstruent clusters in the surface representation. The clusters therefore undergo nasal substitution for example, /mən+tola?/ $\rightarrow$ [mənola?]. This phonological strategy however does not apply to voiced obstruents. In Malay, nasal and voiced obstruent clusters undergo nasal assimilation only, whereby the nasal segment in the prefix assimilates to the place of articulation with the following consonant, as in /məク+dapat/ $\rightarrow$ [məndapat]. The claim made by those previous studies however could not account for nasal and voiceless obstruent clusters root-internally. Differ from nasal and voiceless obstruent clusters at prefix-root juncture, the clusters within the roots are allowed to emerge in the surface representation, as in /simpan/ $\rightarrow$ [simpan] and /kampon/ $\rightarrow$ [kampon].

The situation mentioned above however is slightly different when we consider a non-standard dialect of Malay i.e. Perak dialect (henceforth PD). This dialect presents a different form in the surface representation from SM when treating nasality and voicing at prefix-root juncture. At a prefix-root juncture in the PD, a sequence of nasal and voiceless obstruents is resolved in the same way as in SM, where this cluster undergoes nasal substitution, for example: / $\mathrm{\eta}+$ puji/ $\rightarrow$ [muji] 'to praise' and /mn+pilih/ $\rightarrow$ [mmilih] 'to choose'. It worth mentioning that in the dialect, nasal and voiceless obstruent clusters in root-internally are not resolved by nasal substitution, as occurred in SM. Words like 
/simpan/ and /ləmbap/ are pronounced as [simpan] and [ləmbap], respectively. In this analysis, the blocking of nasal substitution in root-internally in the PD will also be taken into account. It ought to be mentioned that the reverse state occurs in the PD if the obstruent is voiced. In Perak, voiced obstruents following nasals undergo nasal substitution for instance, / $\mathrm{\eta}+$ bagi/ $\rightarrow$ [magi]. Such a process of nasal substitution between nasal and voiced obstruents in Perak never occurs in SM. This raises the question of how this phonological process can be resolved in OT analysis.

To deal with this, it is necessary to posit a constraint that is able to rule out a nasal plus a voiced obstruent cluster, so that a candidate with nasal substitution can emerge as the optimal output. Therefore, I suggest that CRISP-EDGE[s] should be added to the constraint ranking of PD. However, obedience to CRISP-EDGE [s] leads to a violation of another constraint that bans a voiced obstruent from undergoing nasal substitution, that is IDENT[PHAREXP]. Thus, to account for voiced obstruent nasal substitution, as in Perak, these constraints should be ranked in the following order: CRISP-EDGE [s] > IDENT [PHAREXP].

\section{Data}

Data for this study were based on secondary data from previous studies of Malay. For this, the work of Ahmad (1991) was referred to. Work by Ahmad (1991) was used to analyse the phenomenon of nasality and voicing in PD.

As well as the data from Ahmad, an interview method was also used for the analysis to supplement data from the previous study. The data obtained from the previous study was not sufficient for the analysis. More data were needed in order to see how nasal and voiced/voiceless obstruent clusters really behave in the dialect. In order to get more data, five native speakers of Perak were interviewed. 


\section{Proposed Analysis: constraint-based analysis}

This section discusses how nasality and voicing are treated in PD. AS was mentioned above, nasal and voiceless obstruent clusters are not prohibited root-internally in PD. We begin the discussion of nasal and voiceless obstruent clusters within roots by first observing the data listed in the following table:

$\begin{array}{lll}\text { SM } & \text { Perak } & \\ \text { tenkat } & \text { tenkat } & \text { 'level' } \\ \text { tonkat } & \text { tonkat } & \text { 'walking stick' } \\ \text { kampon } & \text { kampon } & \text { 'village' } \\ \text { təmpat } & \text { təmpat } & \text { 'place' } \\ \text { simpan } & \text { simpan } & \text { 'to keep' } \\ \text { lambat } & \text { lambat } & \text { 'late' } \\ \text { pintu } & \text { pintu } & \text { 'door' }\end{array}$

Table 1. Nasal and voiceless obstruent clusters in Perak (Ahmad, 1991).

As illustrated in the above data, nasal and voiceless obstruent clusters within the roots appear in the surface representations of PD, the same as in SM. Observe that words such as [ten.kat], [kam.pon] and [təm.pat] in Perak do not undergo any phonological processes that serve to eliminate nasal and voiceless obstruent clusters, such as nasal substitution, nasal deletion or epenthesis. The above data obviously show that, despite the fact of nasal substitution, which is normally applied in SM to rid the language of nasal and voiceless obstruent clusters, it is however blocked within the roots in PD.

It is worth mentioning that the situation discussed above is also found in other languages that do not allow a sequence of nasal and voiceless obstruents, but that they emerge in the surface representation within the roots. One of those languages is Indonesian. The nasal substitution that is generally applied in Indonesian, to eliminate nasal and voiceless obstruent sequences at prefix-root junctures, is blocked at rootinternal level as well. The consequence of blocking nasal substitution in Indonesian results in a sequence of homorganic nasal and voiceless obstruents in the surface representation, as exemplified below: 


$\begin{array}{lll}\text { /əmpat/ } & \text { [əmpat] } & \text { 'four' } \\ \text { /untuk/ } & \text { [untuk] } & \text { 'for' } \\ \text { /munkin/ } & \text { [munkin] } & \text { 'maybe' }\end{array}$

Table 2. Root-internal occurrences of NCc in Indonesian (from Pater 1999: 75; 2001)

Such a problem occurring in Indonesian has received much attention among theoretical linguists, particularly within OT (e.g. Pater 1999, 2001), as to why nasal substitution is blocked within roots. This poses a challenge to the theory when explaining the blocking of nasal substitution at root-internal position. In explaining the lack of nasal substitution at root-internal position, McCarthy and Prince (1994b, cited in Pater 1996) claim that 'a large number of disparate phonological phenomena for instance, reduplicative and otherwise, result in a stricter faithfulness requirement within the root than elsewhere in the word, that is the relative markedness of roots' (see also Urbanczyk, 1996). In OT, this situation is accounted for as faithfulness requirements are more strictly applied within the root than in non-root morphemes, such as affixes (McCarthy and Prince 1995, cited in Kager 1999: 75). To capture this situation, McCarthy and Prince (1994a) proposed a general ranking schema where root-specific versions of faithfulness constraints are ranked higher than the general version of these constraints: RootFaithfulness >> Faithfulness.

Returning to our discussion of PD, since nasal substitution is also blocked within roots in the dialect, a root-specific constraint, which bans root-internal nasal substitution, is needed for the analysis of Perak. The relevance constraint of faithfulness that is able to capture the blocking of nasal substitution is UNIFORMITY, as defined below:

UNIFORMITY ('No Coalescence') (McCarthy and Prince, 1999: 296)

No element of $S_{2}$ has multiple correspondents in $S_{1}$.

For $x, y \in S_{1}$ and $z \in S_{2}$ if $x R z$ and $y R z$, then $x=y$.

We will see then, that UNIFORMITY, which is the general version of the faithfulness constraint, is ranked beneath the root-specific version of this constraint, i.e. 
UNIFORMITY-ROOT, in the constraint ranking of PD. The root specific constraint, UNIFORMITY-ROOT is defined below:

\section{UNIFORMITY-ROOT}

The output reflects the precedence structure of the input segments of the roots, and vice versa.

In the case where nasal substitution is blocked root-internally, UNIFORMITY-ROOT is ranked high so as to allow output containing a sequence of nasal and voiceless obstruents. There is a functional explanation of why nasal and voiceless obstruent sequences are allowed to be present root-internally. As asserted in Pater (1999), rootinternal segments are more resistant to phonological processes than segments in other positions (cited in Kager 1999: 75). In some of the morphological literature (e.g.: Mascaró 1976; Kiparsky 1982, 1993b; cf. Kager 1999) it is said that 'there is a well-known class of processes that apply only across morphemes but fail to apply within the roots' (cf. Kager 1999: 75). That is the reason why sequences of nasal and voiceless obstruents function root-internally in Perak and thus do not undergo the regular process, nasal substitution.

Before we proceed to the analysis of how UNIFORMITY-ROOT prevents rootinternal segments from undergoing nasal substitution, we consider first what has been discussed in the relevant literature about this constraint. Pater $(1999,2001)$, for example, captured the case of the blocking of nasal substitution in Indonesian by applying the idea of McCarthy and Prince (1994b). Two root-specific constraints, LINEARITY-ROOT and UNIFORMITY-ROOT were used. ${ }^{1}$ I exemplify in the following tableaux how Pater makes use of these two root-specific constraints to analyse the lack of nasal substitution in Indonesian:

\begin{tabular}{|l||c|c|c|}
\hline$/ \partial \mathrm{m}_{1} \mathrm{p}_{2}$ at/ & LINEARITY-ROOT & ${ }^{*}$ NÇ & LINEARITY \\
\hline \hline a. $ә \mathrm{~m}_{12}$ at & $* !$ & & $*$ \\
\hline b. ${ }^{*} \partial \mathrm{m}_{1} \mathrm{p}_{2}$ at & & $*$ & \\
\hline
\end{tabular}

Tableau 1. Root-internal NÇ tolerance: ROOTLIN >>*NÇ (adapted from Pater 1999: 275).

\footnotetext{
${ }^{1}$ Pater's analysis concerning nasal substitution in Indonesian applied two constraints: LINEARITY is used in his earlier analysis, but UNIFORMITY in the revisited analysis on nasal substitution in Austronesian. According to McCarthy (1995), LINEARITY and UNIFORMITY are used to ban metathesis and coalescence, respectively.
} 


\begin{tabular}{|l||c|c|c|}
\hline$/ \partial \mathrm{m}_{1} \mathrm{p}_{2}$ at/ & UNIFORM ROOT & ${ }^{*} \mathrm{NC}$ & UNIFORM \\
\hline \hline a. $ə \mathrm{~m}_{12}$ at & $* !$ & & \\
\hline b. ${ }^{(\odot} \partial \mathrm{m}_{1} \mathrm{p}_{2}$ at & & $*$ & $*$ \\
\hline
\end{tabular}

Tableau 2. Root-internal NC⿺ tolerance: UNIFORMITY-ROOT > $>{ }^{*}$ NC $>>$ UNIFORMITY (adapted from Pater 2001: 162)

The above tableaux clearly show that the root-specific constraints, LINEARITYROOT and UNIFORMITY-ROOT, play important roles in accounting for the blocking of nasal substitution root-internally in Indonesian. According to Pater (2001), by ranking the root-specific constraints UNIFORMITY-ROOT or LINEARITY-ROOT above *NC, nasal substitution can certainly be blocked from occurring within roots in Indonesian. To ensure nasal substitution is not blocked at prefix junctures, *NÇ must outrank UNIFORMITY or LINEARITY, so that nasal substitution would continue to apply, as exemplified in the tableau below.

\begin{tabular}{|l|l|c|c|}
\hline$/$ mə ${ }_{1} \mathrm{p}_{2}$ aksa/ & UNIFORMROOT & ${ }^{*}$ NC & UNIFORM \\
\hline a. ${ }^{\varpi}$ məm $_{12}$ aksa & & & $*$ \\
\hline b. məm ${ }_{1} \mathrm{p}_{2}$ aksa & & $* !$ & \\
\hline
\end{tabular}

Tableau 3. Nasal substitution is unblocked at prefix junctures in Indonesian: UNIFORMROOT > *NC >> UNIFORM (adapted from Pater, 2001: 161).

As we can see in the above tableau, nasal substitution continues to apply at prefix junctures by employing the constraint ranking: UNIFORM-ROOT $\gg$ *NC $\gg$ $>$ UNIFORM. Since the root-specific constraint is able to block nasal substitution only within a root, so this constraint is not violated by candidate (a), which undergoes nasal substitution. This candidate, however, violates UNIFORMITY, since the sequence of nasal and voiceless obstruents at the prefix juncture in the input is substituted into a single segment in the output. Considering the case under discussion, I am going to make use of Pater's analysis (2001) in order to capture the blocking of nasal substitution within roots in Perak, where a root-specific constraint, UNIFORMITY-ROOT, will be used in this analysis.

Since root-internal nasal and voiceless obstruent clusters in Perak are not resolved by nasal substitution, we need a root-specific faithfulness constraint, as discussed above, 
i.e. UNIFORMITY-ROOT, which is able to block the cluster from undergoing nasal substitution. By considering UNIFORMITY-ROOT in the ranking, a candidate without nasal substitution is preferred, i.e. [kam $\left.\mathrm{p}_{2} \mathrm{O}\right]$ ] is preferred over $*\left[\mathrm{kam}_{12} \mathrm{O \eta}\right]$, and thus emerges as the optimal output, as exemplified in the following tableau:

Tableau 4. Constraints interaction: UNIFORMITY-ROOT >> UNIFORMITY

\begin{tabular}{|l||c|c|}
\hline$/$ kam $_{1} \mathrm{p}_{2}$ on/ & UNIFORMITY-ROOT & UNIFORMITY \\
\hline \hline a. kam $_{1} \mathrm{p}_{2}$ on & & \\
\hline b. kam $_{12}$ on & $* !$ & \\
\hline
\end{tabular}

In the process of prefixation to monosyllabic words, schwa is epenthesized to break up the sequence of nasal and voiceless obstruents, since the voiceless obstruent is not deleted, even though the nasal final prefix is attached to it for example, /mən+pam/ $\rightarrow$ [məウəpam]. This solution of epenthesizing a schwa can also be applied to eliminate a sequence of nasal and voiceless obstruents within a root. Thus, the potential candidate if schwa epenthesis were to apply is *[kaməpon]. This candidate involves an additional correspondent in the output. Under Correspondence Theory, the constraint that this candidate violates is DEP-IO. This constraint can formally be defined below.

\section{DEP-IO}

Every segment in the input must have a correspondent in the output.

For this constraint, DEP-IO, and the other two faithfulness constraints, UNIFORMITY and UNIFORMITY-ROOT, discussed above, I establish the following constraint ranking for PD.

DEP-IO >> UNIFORMITY-ROOT > UNIFORMITY

\begin{tabular}{|c|c|c|c|}
\hline$/ \mathrm{kam}_{1} \mathrm{p}_{2} \mathrm{o \eta} /$ & DEP-IO & UNIFORMITY-ROOT & UNIFORMITY \\
\hline a. $\mathrm{kam}_{1} \mathrm{p}_{2} \mathrm{o \eta}$ & & & \\
\hline b. kam $_{12}$ on & & $* !$ & \\
\hline c. $k a m_{1} ә p_{2}$ on & $* !$ & & \\
\hline
\end{tabular}

Tableau 5. [Constraint ranking: DEP-IO >> UNIFORMITY-ROOT >> UNIFORMITY 
Here we see that epenthesis is not a better way to break up the cluster as DEP-IO is highly ranked, as in candidate (c). The root-specific constraint, UNIFORM-ROOT, blocks candidate (a) from undergoing nasal substitution. Therefore it is chosen as the winner. However, candidate (b) with nasal substitution violates UNIFORMITY-ROOT. I illustrate

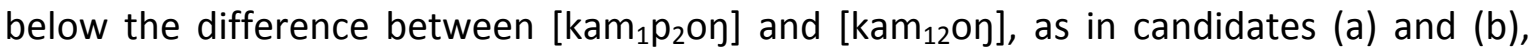
respectively. Candidate (b) with nasal substitution violates the root-faithfulness constraint, UNIFORMITY-ROOT. The subscripted number is used to indicate the correspondence relationship.

Correspondent diagram of UNIFORMITY-ROOT violation

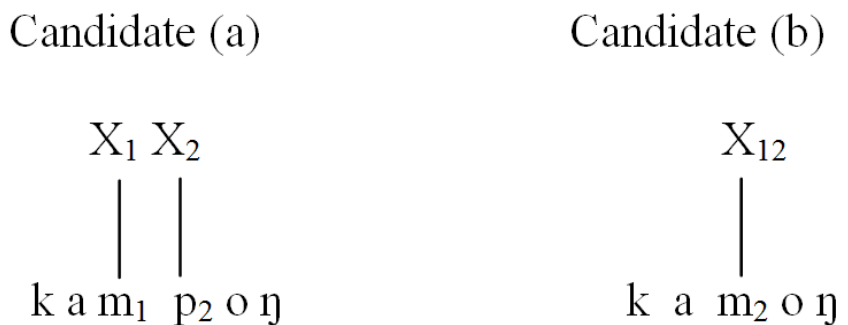

As well as the above candidates, we shall consider other potential candidates that might be generated. Another potential candidate that must be taken into consideration is *[kapon]. In *[kapon], the nasal segment is deleted and this has resulted in one segment in the input having no correspondent in the output. The relation between input and output is called Faithfulness-10, where faithfulness to the input and output identity is a type of requirement in which a pair of representations must be identical, as stated in Correspondence Theory (McCarthy and Prince, 1995, cited in Kager, 1999: 24). In this case, the Faithfulness-IO constraint that is crucial to account for nasal deletion is MAX-IO:

MAX-IO (Kager, 1999: 24)

Every segment in the input must have a correspondent in the output.

The constraint above requires every element in the input to have a correspondent in the output. The violation of MAX-IO in the suboptimal candidate *[kapon] is illustrated in the correspondence diagram, below: 
Correspondence diagram for nasal deletion: [kampon] $\rightarrow{ }^{*}$ [kapoy].

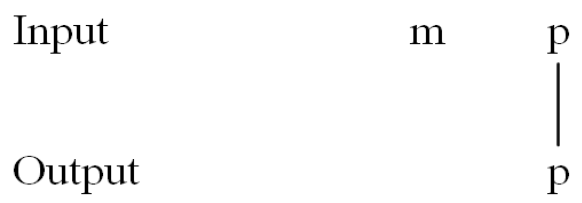

The deletion of the nasal segment in the above candidate, ${ }^{*}[$ kapon] results in the obedience of a constraint named CRISP-EDGE [s] which can be defined below:

\section{CRISP-EDGE [s]}

No element belonging to a syllable may be linked to an adjacent syllable.

Considering the potential candidate ${ }^{*}[$ kapon] in the tableau, I establish the following part of the constraint ranking: DEP-IO > MAX-IO $>$ UNIFORM-ROOT > C CRISPEDGE [s] >> UNIFORM. Now we have two relevant faithfulness constraints, DEP-IO and MAX-IO, in the ranking for further evaluation.

$$
\text { DEP-IO > MAX-IO > UNIFORM-ROOT > UNIFORMITY }
$$

\begin{tabular}{|c|c|c|c|c|c|}
\hline$/$ kam $_{1} \mathrm{p}_{2} \mathrm{on} /$ & DEP-IO & MAX-IO & UNIFORMITY-ROOT & CRISP-EDGE [s] & UNI \\
\hline a. ${ }^{\prime} \mathrm{kam}_{1} \mathrm{p}_{2} \mathrm{o \eta}$ & & & & * & \\
\hline b. $\mathrm{kam}_{12} \mathrm{O \eta}$ & & & $* !$ & & \\
\hline c. $\mathrm{kam}_{1} \partial \mathrm{p}_{2} \mathrm{o \eta}$ & $* !$ & & & & \\
\hline d. $k^{\prime} p_{2}$ on & & $* !$ & & & \\
\hline
\end{tabular}

Tableau 6. [Constraint ranking: DEP-IO > MAXFIO > UNIFORM-ROOT > UNIFORMITY

As can be seen, candidates (c) and (d), which undergo schwa epenthesis and nasal deletion respectively, to eliminate nasal and voiceless obstruent clusters, are ruled out because the candidates incur violation of DEP-IO and MAX-IO, respectively. Candidate (b), which undergoes nasal substitution, violates UNIFORMITY-ROOT. Although nasal substitution is a process of merging two segments in the input into a single segment in the output, which results in one segment less in the output, it does not however violate the faithfulness constraint, MAX-IO, as with candidate (b). Indeed, MAX-IO requires every 
segment in the input to have a correspondent in the output; in nasal substitution however, the two [mp] segments share a single output correspondent (Pater, 2001: 167). Therefore, candidate (a) with lack of nasal substitution is chosen as the optimal output as this candidate violates none of the constraints.

We saw from the above discussion that in order for a candidate without nasal substitution to emerge as the optimal output, the root-specific faithfulness constraint, UNIFORMITY-ROOT, is high in the ranking. This constraint is able to rule out any candidate with nasal substitution as it requires the output segments to be as faithful as possible to the input segments. As $/ \mathrm{kam}_{1} \mathrm{p}_{2} \mathrm{o \eta} /$ is a root word, the output must be faithful to the input which is a root.

We now should move on to the next discussion of nasal and voiceless obstruent clusters at prefix-root junctures in Perak. The same as in SM, PD disfavours nasal and voiceless obstruent clusters in the surface representation at this morphological domain.

As stated in Ahmad (1991: 54), there are two prefixes ending with a final nasal in Perak: $/ \mathrm{\eta}+/$, a verb forming prefix, and a noun forming a prefix, /pə $\eta+/$. The verb forming prefixes, i.e. the velar nasal $/ \mathrm{h+} /$, has two allomorphs, $/ \mathrm{\eta}+/$ and $/ \mathrm{m} ə \mathrm{\eta}+/$. These two allomorphs can be used interchangeably in the dialect. Thus, he claims that words like /n-

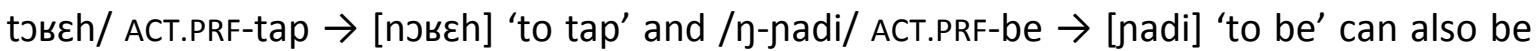
pronounced as [mənэвєh] and [mənadi], respectively (Ahmad 1991: 55). However, the form with velar nasal $/ \mathrm{h}+/$ is used more prominently in Perak compared to the other one which has a sound more like SM.

Those prefixes, / $\mathrm{\eta}+/, / \mathrm{m} ə \mathrm{\eta}+/$ and $/ \mathrm{p} ə \mathrm{\eta}+/$, exhibit the same phonological behaviour where the nasal segments in the prefixes undergo phonological alternation, as can be seen in the following data:

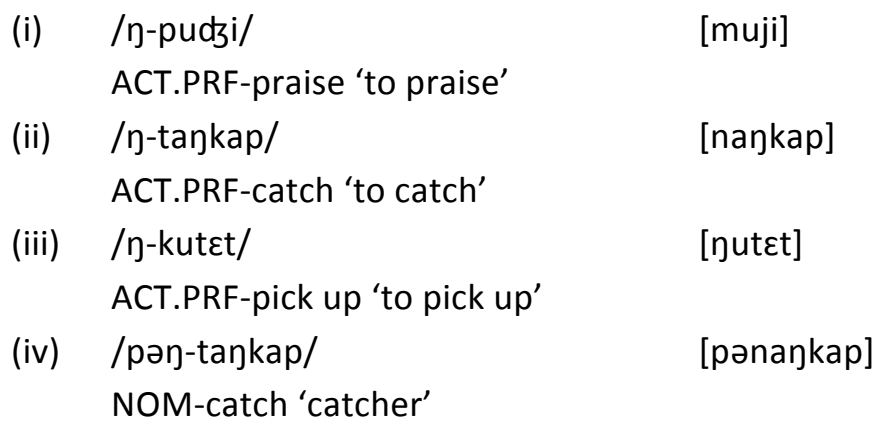



(v) /pən-kajsh/
[pənajoh]
NOM-ride 'rider'
(vi) /n-tวвعh/
[กวвहh]
ACT.PRF-tap 'to tap'

Table 3. Nasal and voiceless obstruent clusters in Perak

It is clear, from the above list, that a sequence of nasal and voiceless obstruents undergoes nasal substitution in Perak. Since nasal substitution at a prefix-root juncture is used to break up the cluster, UNIFORMITY is violated, as the two segments in the input are mapped to a single segment in the output. Hence, UNIFORMITY must be ranked beneath the other faithfulness constraints in the hierarchy. From this, the output undergoes nasal substitution and can emerge as a winner.

*NC in Pater's analysis is ranked beneath the root-specific constraint, UNIFORMITY-ROOT, mainly to ensure that a sequence of root-internal nasal and voiceless obstruents does not undergo nasal substitution. An important point that must be addressed here is that, in this analysis, CRISP-EDGE, which bans any element linked to a prosodic word and may be linked to a prosodic category external to that prosodic word, will be used Besides that, CRISP-EDGE is also crucial to rule out nasal and voiced obstruent clusters in the surface representation. In order to account for voiced obstruent nasal substitution in the Perak, which allow voiced obstruents to undergo nasal substitution, I will make use of the constraint CRISP-EDGE [s], which has been used by Pater (2001) to analyse the same sequence in Muna when undergoing nasal substitution. As we shall see later in this section, CRISP-EDGE [s] becomes more crucial in accounting for nasal and voiced obstruent clusters at prefix-root junctures in PD. As I will demonstrate, this constraint is able to rule out candidates with a sequence of nasal and voiced obstruents in the surface representation at prefix junctures.

As just mentioned above, CRISP-EDGE [s] rules out candidates with both nasal and voiceless/voiced obstruent clusters in the surface representation. This means this constraint will prevent $*\left[m_{1} p_{2} u d z i\right]$ from emerging as a winner. The only candidate that this constraint prefers is a candidate with nasal substitution, i.e. a candidate without a nasal and voiceless obstruent cluster. The potential candidate is [ $\left.m_{12} u d z i\right]$. Although this candidate obeys CRISP-EDGE [s], it does violate another constraint which bans nasal substitution i.e. UNIFORMITY. 
Putting together all the constraints we have discussed thus far, I establish the following part of the constraint hierarchy for PD: DEP-IO > MAX-IO $\gg$ UNIFORM-ROOT >> CRISP-EDGE [s] >> EDGE-INTEG >> UNIFORM.

\begin{tabular}{|l|c|c|c|c|c|}
\hline$/ \mathrm{p}_{1}+\mathrm{p}_{2} u \mathrm{udz}_{3} /$ & DEP- IO & MAX-IO & UNI- ROOT & CRISP-EDGE[s] & UNI \\
\hline a. $\mathrm{m}_{12} \mathrm{udzi}$ & & & & & $*$ \\
\hline b. $\mathrm{m}_{1} \mathrm{p}_{2} \mathrm{udzi}$ & & & & $* !$ & \\
\hline c. $\mathrm{m}_{1} \partial \mathrm{p}_{2}$ udzi & $* !$ & & & & \\
\hline d. $\mathrm{p}_{2}$ udzi & & $* !$ & & & \\
\hline
\end{tabular}

Tableau 7. Nasal and voiceless obstruent sequences at prefix-root junctures in Perak.

All candidates in the above tableau satisfy PROSODIC STEM, as the stem contains two syllables. In order to eliminate nasal and voiceless obstruent sequences at prefix junctures, schwa is epenthesized between the two segments, as in candidate (c), and the nasal prefix is deleted, as in candidate (d). This evaluation reveals that the epenthesis of schwa and nasal deletion in candidates (c) and (d), respectively, can never be optimal, because these candidates disobey DEP-IO and MAX-IO, respectively, which are ranked higher in the hierarchy. The competing candidates, (a) and (b), do not violate these constraints. Without undergoing nasal substitution, candidate (b) obeys UNIFORM, because this constraint works against segmental fusion or coalescence (McCarthy \& Prince 1999). This candidate, however, violates CRISP-EDGE [s], as the two segments are doubled-linked. The diagram for CRISP-EDGE [s] violation of this candidate is illustrated below. Since CRISP-EDGE [s] is ranked above UNIFORMITY, so candidate (b) is ruled out. Therefore, candidate (a), with nasal substitution, is the winner, as it only violates the latter. 
Diagram of CRISP-EDGE [s] violation: [ $\mathrm{m}_{1} \mathrm{p}_{2} \mathrm{udzi}$ ] with multiple linking.
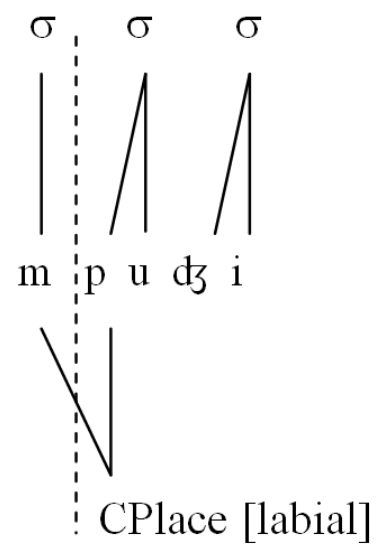

Another potential candidate that must be taken into consideration is $*\left[\eta_{1} p_{2} u d z i\right]$. The nasal segment in this potential candidate is not homorganic to the following voiceless obstruent. Thus it violates a constraint named NAS ASSIMILATION, as defined below:

\section{NAS ASS}

A nasal must share place features with a following consonant.

Following the above analysis, the potential candidate ${ }^{*}\left[\eta_{1} p_{2} u d z i\right]$ and the constraint NAS ASS will be added into the constraint ranking of Perak for further evaluation. The relevant constraint ranking is now as follows: DEP-IO $\gg$ NAS ASS $>>$ MAXIO >> UNIFORM-ROOT >> CRISP-EDGE [s] >> UNIFORM.

\begin{tabular}{|c|c|c|c|c|c|c|}
\hline$/ \eta_{1}+p_{2} u d 3 i /$ & DEP-IO & NAS ASS & MAX-IO & UNI-ROOT & CRISP-EDGE[s] & UNI \\
\hline a. $\mathrm{m}_{12} \mathrm{udzi}$ & & & & & & $*$ \\
\hline b. $m_{1} p_{2} u d 3 i$ & & & & & $* !$ & \\
\hline c. $\mathrm{m}_{1}$ әр $\mathrm{p}_{2} \mathrm{udzi}$ & $* !$ & & & & & \\
\hline d. $p_{2} u d z i$ & & & $* !$ & & & \\
\hline e. $\eta_{1} p_{2} u d d_{3} i$ & & $* !$ & & & & \\
\hline
\end{tabular}

Tableau 8. Constraint ranking for Perak

From the above discussion, we note that nasal and voiceless obstruent clusters are disfavoured at prefix-root junctures in the PD. But what about the occurrence of the same cluster at prefix-prefix root junctures in the dialect? Are nasal and voiceless obstruent 
clusters also banned? This merits a question since the cluster can also occur at prefixprefix root junctures, as in SM. As Ahmad (1991: 80) says, most derived words in Perak have only one layer of prefixation or suffixation. Roots can only be attached to one prefix or suffix, or a combination of both, but not a sequence of the two. From this, it means that PD cannot receive more than one prefix in prefixed words as in SM. Thus, multiple prefixes cannot possibly be found in the vocabulary of Perak.

Now we see how voiced obstruents in the dialect undergo nasal substitution. Why does a sequence of nasal and voiced obstruent not need to undergo nasal substitution? This is because phonetically, the sequence allows a more leisurely rising of the velum than nasal and voiceless obstruents (Huffman 1993: 310, cited in Pater 1999). Thus, there is no need for a voiced obstruent following a nasal segment to undergo nasal substitution. Perak dialect of Malay, however, proves the fact that a voiced obstruent following a nasal segment will also undergo nasal substitution. This interesting process that occurs in a non-standard Malay dialect cannot be found in SM. Based on evidence from the data for Perak, I claim that nasal and voiced obstruent clusters also undergo nasal substitution. Thus this analysis will be discussing this issue further, using apparatus available within OT. Before we proceed to the analysis, let us first observe the Perak data.

$\begin{array}{ll}\text { (i) } / \eta \text {-bagi/ } & \text { [magi] } \\ \text { ACT.PRF-give 'to give' } & \text { [napat] } \\ \text { (ii) / } \text {-dapat/ } & \text { ACT.PRF-obtain 'to obtain' } \\ \text { (iii) } / \eta \text {-gosok/ } & \text { [noso?] } \\ \text { ACT.PRF-brush 'to brush' } & \\ \text { (iv) } / \eta \text {-basuh/ } & \text { [masoh] } \\ & \text { ACT.PRF-wash 'to wash' }\end{array}$

Table 4. Nasal and voiced obstruent clusters in Perak

The above data reveal that voiced obstruents after nasals also undergo substitution. The question to be addressed in this subsection is why the initial voiced obstruent of the root needs to be substituted since the language does licence nasal-voiced obstruent clusters in a word. What argument in OT can be offered to explain the phenomenon of substituting a voiced obstruent following a nasal segment? 
In Pater's analysis (2001), a voiced obstruent can be blocked from undergoing nasal substitution by ranking IDENT [PHAREXP] above CRISP-EDGE [PrWD] ${ }^{2}$ (Pater 2001: 176). The following tableau demonstrates how this ranking blocks a voiced obstruent from undergoing nasal substitution, but not a voiceless obstruent.

\begin{tabular}{|c|c|c|}
\hline$/ \mathrm{mə \eta}_{1}+\mathrm{b}_{2}$ əli/ & IDENT[PHAREXP] & CRISP-EDGE[PrWD] \\
\hline a.Fməm ${ }_{1} b_{2}$ əli & & * \\
\hline b. məm $m_{12} \partial l i$ & $* !$ & \\
\hline \multicolumn{3}{|l|}{$/ m \partial \eta_{1}+p_{2}$ ilih/ } \\
\hline c.Fməm 12 ilih & $*$ & \\
\hline d. məm $_{1} p_{2}$ ilih & & $* !$ \\
\hline
\end{tabular}

Tableau 9. IDENT [PHAREXP] >> CRISP-EDGE [PrWD] (Pater 2001: 176)

We can see in the above tableaux that a voiced obstruent following a nasal segment can be blocked from undergoing nasal substitution by the constraint ranking: IDENT [PHAREXP] > CRISP-EDGE [PrWD]. However, with the ranking reversed, CRISP-EDGE [PrWD] >> IDENT [PHAREXP], both voiceless and voiced obstruents are subject to fusion (Pater 2001: 176), as the following tableau demonstrates:

\begin{tabular}{|c|c|c|}
\hline$/ \mathrm{m} \mathrm{y}_{1}+\mathrm{b}_{2}$ əli/ & CRISP-EDGE[PrWD] & IDENT[PHAREXP] \\
\hline a. məm ${ }_{1} b_{2}$ əli & *! & \\
\hline b. $\mathrm{m}^{\circ} \mathrm{m}_{12} \partial \mathrm{li}$ & & $*$ \\
\hline$/ m \partial \eta_{1}+p_{2} i l i h /$ & & \\
\hline c. məm $_{12}$ ilih & & * \\
\hline d. məm $_{1} p_{2}$ ilih & $* !$ & \\
\hline
\end{tabular}

Tableau 10. CRISP-EDGE [s] >> IDENT [PHAREXP] (Pater 2001)

Considering the ranking CRISP-EDGE[PrWD] >> IDENT[PHAREXP], as in the above tableau, as well as a voiceless obstruent, a voiced obstruent following a nasal segment at a prefix-root juncture can also undergo nasal substitution. To account for the case in

\footnotetext{
${ }^{2}$ Please refer to Pater (2001) for more details.
} 
Perak, nasal substitution with voiced obstruents can be attributed to the ranking of IDENT [PHAREXP] beneath CRISP-EDGE [s], as demonstrated in the following tableau:

\begin{tabular}{|l|l|l|}
\hline$/ \mathrm{b}_{1}+\mathrm{b}_{2} \mathrm{agi} /$ & CRISP-EDGE[s] & IDENT [PHAREXP] \\
\hline a. ${ }^{\nabla} \mathrm{m}_{12}$ agi & & $*$ \\
\hline b. $\mathrm{m}_{1} \mathrm{~b}_{2}$ agi & $* !$ & \\
\hline
\end{tabular}

Tableau 11. Nasal substitution with voiced obstruents in Perak: CRISP-EDGE [s] >> IDENT [PHAREXP]

By considering the constraint ranking CRISP-EDGE [s] >> IDENT [PHAREXP] above, I establish a new hierarchy of constraint ranking for PD to account for voiced obstruent nasal substitution.

\begin{tabular}{|l|l|c|c|c|c|c|c|}
\hline$/ \mathrm{b}_{1}+\mathrm{b}_{2}$ agi/ & $\begin{array}{l}\text { DEP } \\
\text { IO }\end{array}$ & NAS ASS & MAX -IO & UNI-ROOT & CRISP-EDGE[s] & $\begin{array}{l}\text { IDENT } \\
\text { [PHAREXP] }\end{array}$ & UNI \\
\hline a. $\mathrm{m}_{12}$ agi & & & & & & $*$ & $*$ \\
\hline b. $\mathrm{m}_{1} \mathrm{~b}_{2}$ agi & & & & & $* !$ & & \\
\hline c. $\mathrm{n}_{1} \mathrm{~b}_{2}$ agi & & $* !$ & & & & & \\
\hline
\end{tabular}

Tableau 12. Voiced obstruent nasal substitution in PD

The failed candidate, (c), violates NAS ASS as the nasal segment in the prefix does not assimilate to the place of articulation to the following onset consonant. Since the NAS ASS constraint is ranked higher in the hierarchy, candidate (c) is ruled out. The competing candidates now are (a) and (b). As we see, by ranking CRISP-EDGE [s] above IDENT [PHAREXP], the candidate with a nasal and voiced obstruent cluster, candidate (b), is ruled out. Thus candidate (a) emerges as the winner as it only violates the latter constraint, IDENT [PHAREXP], which bans voiced obstruents from undergoing nasal substitution. It is now apparent from the above tableau that the CRISP-EDGE [s] constraint cannot limit voiced obstruents from undergoing nasal substitution in Perak. 


\section{Conclusion}

The discussion above has discussed the issue of nasality and voicing focusing on non-standard dialect of Malay i.e. in Perak dialect. As we have seen in the analysis, nasal and voiceless obstruent clusters are not entirely prohibited from emerging in the surface representation. The clusters are allowed root-internally. In the process of prefixation to a nasal final prefix, nasal substitution violates UNIFORMITY as the constraint works against segmental fusion or coalescence (McCarthy \& Prince 1999). This constraint leads to a straightforward account of the lack of nasal substitution root-internally in Perak by employing UNIFORMITY-ROOT. As mentioned, such cases are captured, by McCarthy and Prince (1995b), by a general ranking schema in which a root-specific version of the faithfulness constraints must be ranked higher than the general version of these constraints, (cited in Kager 1999: 76). By ranking UNIFORMITY-ROOT above UNIFORMITY, a sequence of nasal and voiceless obstruents can be prevented from undergoing nasal substitution within a root. The preservation of this cluster within roots, as in PD, is the consequence of a candidate's output best satisfying the root-specific constraint UNIFORMITY-ROOT in the hierarchy.

The occurrence of nasal and voiceless obstruent clusters at prefix-root junctures is, on the other hand, completely banned in the dialect. As discussed, nasal substitution is also the way to break up clusters at prefix-root junctures. The other cluster discussed in this analysis is nasal and voiced obstruents. As was discussed, nasal and voiced obstruent clusters are allowed in the surface representation in SM. Therefore, the clusters do not have to undergo nasal substitution, as nasal and voiceless obstruent do. In contrast, nasal and voiced obstruent clusters also undergo nasal substitution as occurs in the Perak dialect. By employing the constraint of faithfulness to obstruent voicing IDENT[PHAREXP], the case where voiced obstruents following nasals at prefix junctures in Perak undergo nasal substitution is an explainable phenomenon. IDENT[PHAREXP] is ranked above CRISP-EDGE[s] to stop a voiced obstruent from undergoing nasal substitution in Indonesian (Pater 2001). However, in this study, IDENT[PHAREXP] is ranked beneath CRISP-EDGE[s], so that nasal substitution is not limited to voiceless obstruents. In other 
words, the ranking CRISP-EDGE[s] >> IDENT[PHAREXP] allows both voiced and voiceless obstruents following a nasal segment to undergo nasal substitution.

\section{References}

AHMAD, Zaharani (1991) The phonology and morphology of the Perak dialect, Kuala Lumpur: Institute of Language and Literature.

HASSAN, Abdullah (1974) The morphology of Malay, Kuala Lumpur: Institute of Language and Literature.

HASSAN, Abdullah (1987) Penerbitan kata dalam bahasa Malaysia, Petaling Jaya: Fajar Bakti.

HUfFMAN, Marie K. (1993) "Phonetic patterns of nasalisation and implication for feature specification", in M. K. Huffman and R. A. Krakow (eds.), Phonetics and phonology 5: Nasals, nasalisation and the velum, San Diego, CA: Academic 303-27.

KAGER, René (1999) Optimality theory, Cambridge: Cambridge University Press.

KARIM, Nik Safiah (1995) Malay grammar for academics and professionals, Kuala Lumpur: Institute of Language and Litrature.

KIPARSKY, Paul (1982) "From cyclic phonology to lexical phonology", in H. van der Hulst \& N. Smith (eds.), The structure of phonological representatitons, part 2. Dordrecht: Foris, 131-76.

KIPARSKY, Paul (1993) "Blocking in non-derived environments", in S. Hargus \& E. Kaisse (eds.), Phonetics and phonology IV: studies in lexical phonology, San Diego: Academic Press, 277313.

MASCARÓ, Joan (1976) Catalan phonology and the phonological cycle, PhD thesis, MIT Distributed by Indiana Linguistics Club.

McCARTHY, John J. \& Alan S. Prince (1994a) "The emergence of the unmarked: Optimality in prosodic morphology", Proceedings of the North East Linguistic Society, 24, Graduate Linguistic Student Association, University of Massachusetts, 333-379.

MCCARTHY, John J. \& Alan S. PRINCE (1994b) Prosodic Morphology: an overview. Talks presented at the OTS/HIL Workshop on Prosodic Morphology, University of Utrecht.

McCARTHY, John J. \& Alan S. PrInCE. 1995. Faithfulness and reduplicative identity, available in ROA$60<$ http://ruccs.rutgers.edu/roa.html $>$ 
McCarthy, John J. \& Alan S. PrInCE (1999) Faithfulness and Identity in Prosodic Morphology, in René Kager, Harry van der Hulst \& Wim Zonneveld (eds.) The Prosody-Morphology Interface, Cambridge: Cambridge University Press, 218-384.

OMAR, Asmah (1975) Essays on Malaysian linguistics, Kuala Lumpur: Institute of Language and Literature.

ONN, Farid (1980) Aspect of Malay phonology and morphology: a generative approach, Bangi: National University of Malaysia.

PATER, Joe (1996) "*NC", Proceedings of the North East Linguistics Society, 26, Graduate Linguistic Student Association, University of Massachusetts, Amherst, 227-239.

PATER, Joe (1999) "Austronesian nasal substitution and other NC effects", in René Kager, Harry Van Der Hulst \& Wim Zonneveld (eds.), The prosody-morphology interface, Cambridge: Cambridge University Press, 310-43.

PATER, Joe (2001) "Austronesian nasal substitution revisited", in Linda Lombardi. (ed.), Segmental phonology in Optimality theory: constraints and representations, Cambrige: Cambridge University Press, 159-82.

URBAnczYK, S. (1996) Pattern of reduplication in Lushootsheed, Ph.D dissertation, University of Massachusetts - Amherst. 